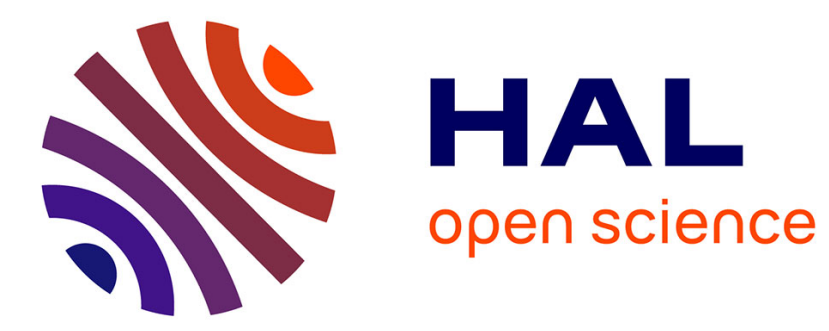

\title{
Using limiting similarity to enhance invasion resistance: Theoretical and practical concerns
}

Manon C M Hess, Elise Buisson, Renaud Jaunatre, François Mesléard

\section{To cite this version:}

Manon C M Hess, Elise Buisson, Renaud Jaunatre, François Mesléard. Using limiting similarity to enhance invasion resistance: Theoretical and practical concerns. Journal of Applied Ecology, 2020, 57 (3), pp.559-565. 10.1111/1365-2664.13552 . hal-02441630

\section{HAL Id: hal-02441630 \\ https://hal.science/hal-02441630}

Submitted on 18 Jan 2020

HAL is a multi-disciplinary open access archive for the deposit and dissemination of scientific research documents, whether they are published or not. The documents may come from teaching and research institutions in France or abroad, or from public or private research centers.
L'archive ouverte pluridisciplinaire HAL, est destinée au dépôt et à la diffusion de documents scientifiques de niveau recherche, publiés ou non, émanant des établissements d'enseignement et de recherche français ou étrangers, des laboratoires publics ou privés. 


\title{
Using limiting similarity to enhance invasion resistance: Theoretical and practical concerns
}

\author{
Manon C. M. Hess ${ }^{1,2,3}$, Elise Buisson ${ }^{2}$, Renaud Jaunatre ${ }^{4}$, François Mesléard ${ }^{2}$ \\ ${ }^{1}$ NGE-GUinTOLI, Saint-Etienne-du-Grès, Tarascon Cedex, France \\ ${ }^{2}$ Institut Méditerranéen de Biodiversité et d'Ecologie marine et continentale (IMBE), Avignon Université, UMR CNRS IRD Aix Marseille \\ Université, IUT Site Agroparc, Avignon Cedex 09, France \\ ${ }^{3}$ Institut de recherche pour la conservation des zones humides méditerranéennes Tour du Valat, Arles, France \\ ${ }^{4}$ Université Grenoble Alpes, Irstea, EMGR, St-Martin-d'Hères, France \\ Correspondence : Manon C. M. Hess, Email: hess@tourduvalat.org ORCID \\ Manon C. M. Hess https://orcid.org/0000-0002-8332-1701
}

How to cite this article: Hess M.C.M., Buisson E., Jaunatre R., Mesléard F. 2019. Using limiting similarity to enhance invasion resistance: Theoretical and practical concerns.Singh I, editor. J Appl Ecol:7. doi: 10.1111/1365-2664.13552

\section{Abstract}

1. The control of invasive species is a central topic of both applied and theoretical research. Understanding how and which ecological theories can be used to improve invasion resistance of plant communities is essential, to design effective control strategies.

2. The theory of limiting similarity, stating that coexistence between species is more limited by competitive exclusion when species share niche properties, is often considered by applied ecologists as a possible approach to limiting plant invasions at the local scale.

3. The complexity of measuring ecological niche overlap between species as well as the difficulty of disentangling niche from fitness processes currently limit the demonstration and application of this theory. Limiting similarity appears to operate at a time-scale that is too long for efficient impact on invasive species' early establishment. It may also be ineffective against invasions in the long term, due to environmental changes and community instability. Finally, limiting similarity is not applicable to the most common situations, where there are multiple co-occurring invasive species or no prior identification of potential invasives.

4. Synthesis and applications. Whether the theory of limiting similarity, predicting competitive exclusion when species display niche similarities, can be successfully applied to limit plant invasions — or not — is an important issue for practitioners facing invasive species. In practice, using limiting similarity to design invasion-resistant plant communities appears to be complex, ineffective and unsuitable for most common situations.

\section{K E Y W O R D S}

biotic resistance, coexistence, competitive exclusion, ecological niche, fitness, invasive species, restoration

\section{INTRODUCTION}

Invasive species are a key driver of biodiversity loss world-wide (MacGeoch et al., 2010). Controlling them (as a conservation objective) is a central topic of both applied (Byun \& Lee, 2017; Clements, Larsen,\& Grenz, 2016; Clewley, Eschen, Shaw, \& Wright, 2012; Connolly et al., 2018) and theoretical research (Catford, Jansson, \& Nilsson, 2009; Davis, Grime, \& Thompson, 2000; Hallett, 
2006; Shea \& Chesson, 2002; Tilman, 2004). Many studies suggest that more resources are invested in post-invasion control and impact reduction than in prevention or early intervention (Simberloff et al., 2013). In this regard, the establishment of a native resistant plant cover after a disturbance (e.g. after restoration activities implying vegetation clearing) is increasingly recommended to impair invasive plant species colonization and local spread (Byun, Blois, \& Brisson, 2018). One of the ecological theories explored by applied ecologists seeking to improve the invasion resistance of plant communities is limiting similarity. The limiting similarity theory derives from the classical niche theory, which states that a species persists under a specific range of conditions (Hutchinson, 1959) and that an overlap in ecological niche with another species can prevent establishment in a community (Case, 1983; Diamond, 1975; MacArthur \& Levins, 1967). Limiting similarity theoretically means that competitive exclusion will limit the coexistence of species sharing the same ecological niche (Abrams, 1983; Funk, Cleland, Suding,\& Zavaleta, 2008; MacArthur \& Levins, 1964, 1967). This hypothetical competitive exclusion is therefore considered as a possible way to reinforce the biotic resistance of native communities (Funk et al., 2008; Yannelli, Hughes, \& Kollmann, 2017). In practical terms, attempts to apply limiting similarity involve reassembling plant communities so that the dominant species' ecological niche is similar to that of a target invader. Price and Pärtel (2013) examined experimental evidence of limiting similarity in invasion resistance and found partial support in artificial communities. In this paper, we go further by challenging the theoretical and practical issues raised by the application of limiting similarity to design invasion-resistant plant communities. We aim at answering the following question: Can we predict the competitive impact of a plant community by measuring niche overlap and therefore applying limiting similarity to enhance invasion resistance, and if so, would it be an efficient approach?

\section{APPLICATIONS OF LIMITING SIMILARITY INVOLVE OVERSIMPLIFICATION}

A species' ecological niche (hereafter termed 'niche') is usually defined as an $n$-dimensional hypervolume (Hutchinson, 1957), characterized by axes of resource use and/or environmental conditions within which populations are able to maintain a longterm average net reproductive rate $\geq 1$ (Gause, 1934; Silvertown, 2004). Originally, this concept was introduced to emphasize the role of habitat and food in defining the niche of an animal (Chase \& Leibold, 2003). Unlike in many animal communities, plants' coexistence is not explained by the trophic niche: all plants consume the same resources (light, water, $\mathrm{CO} 2$, nitrogen, phosphorus, potassium and other macroand micronutrients; Silvertown, 2004). Two niches are hypothesized to be different if there are differences (a) in resource use across time and space, $(b)$ in the ratios of limited resources required and (c) in the conditions for regeneration, or if there is complementarity of life-forms (Cody, 1986; Grubb, 1986; Tilman, 1982). Thus, the niche appears to be a complex, multidimensional concept that currently escapes comprehensive description. Niche differentiation is therefore usually described on a very limited number of axes, such as environmental (e.g. hydrology, salinity, soil texture or drought) or resource gradients (e.g. light or nitrogen) (Silvertown, 2004), although some studies also include space and/or time (Fargione \& Tilman, 2005).

In demonstrations or applications of the limiting similarity theory, niche overlap between species is reduced to similarities quatified by measuring functional traits. The rationale is that these traits relate both to strategies of resource capture and to the effect on the overall pool of resources; they are effect and response traits (Goldberg, 1996; Lavorel \& Garnier, 2002; McGill, Enquist, Weiher, \& Westoby, 2006). Different groups based on similarities in growth form or other morphological or phenological trait similarities have been defined, assuming that species from the same group should have greater niche overlap and compete more intensively than species from different groups (Johansson \& Keddy, 1991; MacArthur \& Levins, 1967). However, most studies found no or very limited support for limiting similarity in invasion resistance (Abella, Craig, Smith, \& Newton, 2012; Byun \& Lee, 2017; Cleland, Larios, \& Suding, 2013; Daneshgar \& Jose, 2009; Emery, 2007; Eriksson, 
Wikström, Eriksson, \& Lindborg, 2006; Fargione, Brown, \& Tilman, 2003; Funk \& Wolf, 2016; Larson et al., 2013; Longo, Seidler, Garibaldi, Tognetti, \& Chaneton, 2013; Öster \& Eriksson, 2012; PrieurRichard, Lavorel, Grigulis, \& Dos Santos, 2000; Turnbull et al., 2005; von Holle, 2005; Yannelli, Karrer, Hall, Kollmann, \& Heger, 2018). While such failures do not necessarily invalidate the limiting similarity theory, they are probably due to an inability to reach the domain of validity of this theory. For instance, there may be an insufficient degree of niche overlap between selected native and invasive species, or perhaps niche processes are not a determining factor in invasion resistance.

\subsection{Getting the degree of niche overlap right is complex}

What degree of niche overlap is required for competitive exclusion?' is one key question that needs to be answered before limiting similarity can be applied successfully. Several categories of similarities between native and invasive species have been explored: in growth form (e.g. C3-grasses, C4-grasses, non-leguminous forbs and legumes; Emery, 2007; Fargione et al., 2003; Prieur-Richard et al., 2000; Symstad, 2000), in life longevity and phenology (e.g. annuals, perennials, early or late seasonal plants; Abella et al., 2012; Cleland et al., 2013; Larson et al., 2013), in morphology (e.g. woodiness, height, presence of taproot; Byun \& Lee, 2017; von Holle, 2005) and/or in physiology (e.g. specific leaf area, relative growth rate, leaf dry-matter content; Byun \& Lee, 2017). The findings from most studies do not support limiting similarity as an efficient, robust way to limit early establishment of invasive species. Among other explanations, this may be because the degree of niche overlap was insufficient to induce competitive exclusion.

\subsection{Limiting similarity may have less impact than differences in fitness on early establishment success}

A non-negligible role of limiting similarity has indeed been demonstrated in plant community assemblage (i.e. more trait divergence between species of a local assemblage than expected under a random null model; Armbruster, 1986; Fukami, Martijn Bezemer, Mortimer, \& van der Putten, 2005; Mason \& Wilson, 2006; Stubbs \& Wilson, 2004; Wilson, 2007; Wilson \& Whittaker, 1995; but see Mahdi, Law, \& Willis, 1989), as well as in invasiveness (i.e. functional similarity to native species facilitates naturalization but hinders invasion; Divíšek et al., 2018; Hamilton et al., 2005). However, its role in early establishment success at the local scale may be limited compared with the effect of differences in fitness (Funk \& Wolf, 2016; Kunstler et al., 2012). Fitness advantage can arise from greater ability to effectively use resources in a specific range of environmental conditions (Freckleton \& Watkinson, 2001; Keddy \& Shipley, 1989; Mesléard, Ham, Boy, van Wijck, \& Grillas, 1993), resulting in a competitive hierarchy (Fargione et al., 2007; Herben \& Goldberg, 2014). Competitive hierarchies have been shown to occur within functional groups (Turnbull, Coomes, Hector, \& Rees, 2004; Turnbull et al., 2005; Wedin \& Tilman, 1993), contrary to the within-group equivalence predicted by limiting similarity (Hubbell, 2005). Accordingly, specific trait values-not necessarily similar to those of the target invader-such as high specific root length (Daneshgar \& Jose, 2009; Funk \& Wolf, 2016), large size or height (Byun \& Lee, 2017), high growth rate (Symstad, 2000), or early access to limiting resources (Longo et al., 2013) have been linked to increased invasion resistance (Drenovsky \& James, 2010). Moreover, competition can be intense between functionally distant species (e.g. between lianas and trees; Schnitzer, Kuzee, \& Bongers, 2005).

Fitness inequality can also arise from a size-related competitive advantage generated through priority effects (Wilsey, Barber, \& Martin, 2015), where the species established first sequester resources, thus depriving later colonizers (Byun, Blois, \& Brisson, 2013; Fukami, 2015; Vance, 1984). Giving reassembled native species a short time advance (i.e. a few weeks) has been shown to create strong priority effects, successfully decreasing invasive species success (e.g. Byun et al., 2013; Grman \& Suding, 2010; Vaughn \&Young, 2015; Young, Stuble, Balachowski, \& Werner, 2016). Several studies concluded that difference in fitness is more important than similarity in niche in determining invasion 
resistance, at least in the short term (Byun et al., 2013; Byun \& Lee, 2017; Firn, MacDougall, Schmidt, \& Buckley, 2010; Funk \& Wolf, 2016; Grman \& Suding, 2010; Kunstler et al., 2012; Larson et al., 2013; Prieur-Richard et al., 2000; Wang, Ge, Zhang, Bai, \& Du, 2013).

Moreover, disentangling niche from fitness processes is not easy, especially when only one invader is tested (e.g. Byun et al., 2013; Dukes, 2002; Sheley \& James, 2010; Symstad, 2000; Walder, Armstrong, \& Borowicz, 2018). When a resident species is the most effective in decreasing the success of an invader belonging to the same functional group, it is impossible to conclude on whether the effect is due to differences in niche or in fitness: the experimental design makes it difficult to rule out the possibility that a similar response could have been observed with invaders from other functional groups, which would support differences in fitness as being more important than niche similarity.

\section{LIMITING SIMILARITY MAY TAKE TOO LONG TO ACT}

There are several reasons to believe that limiting the establishment of an invasive species demands rapid and robust inhibition of invasive species seedling emergence and survival. The seedling stage offers a critical window of opportunity to control invasive species effectively, for two main reasons. First, the seedling stage is the most vulnerable stage in the life cycle of plants (Baskin \& Baskin, 1998; Fenner \& Thompson, 2005). Second, invasive species often exhibit a high growth rate (Dawson, Fischer, \& van Kleunen, 2011; Marushia, Cadotte, \& Holt, 2010; Rejmánek \& Richardson, 1996) and strong priority effects (Dickson, Hopwood, \& Wilsey, 2012; Stuble \& Souza, 2016; Wilsey et al., 2015), thus rapidly becoming competitively superior after establishment (Martin \& Wilsey, 2012).

Competitive exclusion via limiting similarity, which may take several generations (Passarge, Hol, Escher, \& Huisman, 2006), may therefore act at too long a time-scale to successfully hamper invasive species colonization (Abrams, 1983; Price \& Pärtel, 2013; Stohlgren, Barnett, Jarnevich, Flather, \& Kartesz, 2008; Symstad, 2000). Seedlings are not necessarily functionally similar to adults (Hooper \& Dukes, 2010), meaning that it would take too long for the resident species to affect functionally similar invasive species. In support of this, Price and Pärtel (2013) found less effect from limiting similarity on invader colonization (germination, establishment or seedling survival) than on performance (biomass, cover or growth). Limiting similarity thus appears to be an inappropriate approach to hindering the early establishment of invasive species.

But is limiting similarity any more appropriate for limiting invasive species success in the long term? Its long-term efficiency relies heavily on the stability of the community over time, achieved by maintaining species assumed to prevent the development of similar invasive species. Yet, species dominance in a community can decrease over time through succession, raising the risk that species selected for their similarities with the target invasive species will lose their dominance. In this case, a reasonable hypothesis is that the environmental conditions will also become unfavourable for the invasive species. A more appropriate strategy could be to foster a diverse community where a few species are likely to respond favourably to changes in environmental conditions, especially if the community sown is dominated by perennials (Byun \& Lee, 2017; Corbin \& D'Antonio, 2004; Naeem et al., 2000). This might be a surer bet than relying on the capacity of one or a few species resembling the invasive to maintain dominance under changing conditions.

\section{LIMITING SIMILARITY CAN ONLY BE APPLIED TO A SINGLE TARGET INVASIVE SPECIES}

The concept of limiting similarity is only applicable to control a single invasive species (or a group of species occupying the same niche). This implies that the target invasive species has previously been identified. The scope is thus narrowed to situations where the target invasive species (a) is present at the site prior to management or restoration actions (and its propagules are potentially present in the 
soil), or (b) poses a direct threat to the site through being established nearby. However, previously unnoticed invasive species can emerge from persistent seed banks (e.g. Honig, Cowling, \& Richardson, 1992; Pyke, 1990; Shen, Liu, Baskin, Baskin, \& Cao, 2006) through the soil disturbances generated by restoration activities (Fumanal, Gaudot, \& Bretagnolle, 2008). Invasive species established several kilometres away can reach the site through long-distance dispersal abilities (Buchanan, 1989; Renne, Barrow, Johnson Randall, \& Bridges, 2002; Stansbury, 2001). Moreover, there are far more situations where several invasive species co-occur than single-invaded habitats (Kuebbing, Nuñez, \& Simberloff, 2013). The application of limiting similarity may therefore be ineffective in a wide range of common situations, such as when potential invaders are not yet identified and when multiple invaders co-occur.

All these arguments suggest that the application of the theory of limiting similarity to design invasion-resistant plant communities does not seem relevant in most cases. Research efforts should focus on strategies that quickly and significantly reduce invasive species colonization, and that are efficient when there are multiple co-occurring invasive species. Establishing a community displaying a great diversity of functional traits would allow a more effective and stable use of resources over time and space-and the occupation of most of the niches (Sheley, Svejcar, \& Maxwell, 1996). Also, when increasing the number of species in a community, theoretically, the probability of a species being present to be a strong competitor to invasive species increases (Lavorel, Prieur-Richard, \& Grigulis, 1999). Diverse communities may therefore exhibit an increased invasion resistance when fully established. However, diverse communities would include slow growing, low competitive species that would compromise invasion resistance at the first stages of growth. Therefore, in a case where invasive species are already present in the immediate vicinity and thus threatening the site, this strategy may be less effective. Combining this strategy with approaches giving a rapid and strong invasion resistance, for example through priority effects (Hess, Mesléard, \& Buisson, 2019), would seem a more promising way of effectively hinder invasive species' early establishment.

\section{ACKNOWLEDGEMENTS}

We thank Marjorie Sweetko for reviewing the English of the paper and the two anonymous reviewers for helpful comments on the manuscript.

\section{AUTHORS' CONTRIBUTIONS}

M.C.M.H. and F.M. initiated the study. All authors contributed critically to the development of concepts and writing of subsequent drafts, and gave final approval for publication.

\section{DATA AVAILABILITY STATEMENT}

Data have not been archived because this article does not use data.

\section{REFERENCES}

Abella, S. R., Craig, D. J., Smith, S. D., \& Newton, A. C. (2012). Identifying native vegetation for reducing exotic species during the restoration of desert ecosystems. Restoration Ecology, 20(6), 781787. https:// doi.org/10.1111/j.1526-100X.2011.00848.x

Abrams, P. (1983). The theory of limiting similarity. Annual Review of Ecology and Systematics, 14(1), 359-376. https://doi.org/10.1146/ annurev.es.14.110183.002043

Armbruster, W. S. (1986). Reproductive interactions between sympatric Dalechampia species: Are natural assemblages "random" or organized? Ecology, 67(2), 522-533.

https://doi.org/10.2307/1938595

Baskin, C. C., \& Baskin, J. M. (1998). Seeds: Ecology, biogeography, and evolution of dormancy and germination. San Diego, CA: Academic Press. 
Buchanan, R. A. (1989). Pied Currawongs (Strepera graculina): Their diet and role in weed dispersal in suburban Sydney, New South Wales. Proceedings of the Linnean Society of New South Wales, 111, 241-255.

Byun, C., Blois, S., \& Brisson, J. (2013). Plant functional group identity and diversity determine biotic resistance to invasion by an exotic grass. Journal of Ecology, 101(1), 128-139. https://doi.org/ $10.1111 / 1365-2745.12016$

Byun, C., Blois, S., \& Brisson, J. (2018). Management of invasive plants through ecological resistance. Biological Invasions, 20(1), 13-27. https:// doi.org/10.1007/s10530-017-1529-7

Byun, C., \& Lee, E. J. (2017). Ecological application of biotic resistance to control the invasion of an invasive plant, Ageratina altissima. Ecology and Evolution, 7(7), 2181-2192.

https://doi.org/10.1002/ece3.2799

Case, T. J. (1983). Niche overlap and the assembly of island lizard communities. Oikos, 41(3), 427433. https://doi.org/10.2307/3544102

Catford, J. A., Jansson, R., \& Nilsson, C. (2009). Reducing redundancy in invasion ecology by integrating hypotheses into a single theoretical framework. Diversity and Distributions, 15(1), 22-40. https://doi. org/10.1111/j.1472-4642.2008.00521.x

Chase, J. M., \& Leibold, M. A. (2003). Ecological niches: Linking classical and contemporary approaches. Chicago, IL: University of Chicago Press.

Cleland, E. E., Larios, L., \& Suding, K. N. (2013). Strengthening invasion filters to reassemble native plant communities: Soil resources and phenological overlap. Restoration Ecology, 21(3), 390-398. https://doi. org/10.1111/j.1526-100X.2012.00896.x

Clements, D. R., Larsen, T., \& Grenz, J. (2016). Knotweed management strategies in North America with the advent of widespread hybrid Bohemian knotweed, regional differences, and the potential for biocontrol via the psyllid Aphalara itadori Shinji. Invasive Plant Science and Management, 9(1), 60-70. https://doi.org/10.1614/ IPSM-D-15-00047.1

Clewley, G. D., Eschen, R., Shaw, R. H., \& Wright, D. J. (2012). The effectiveness of classical biological control of invasive plants. Journal of Applied Ecology, 49(6), 1287-1295.

https://doi.org/10.1111/j.13652664.2012.02209.x

Cody, M. L. (1986). Structural niches in plant communities. In J. Diamond \& T. J. Case (Eds.), Community ecology (pp. 381-405). New York, NY:Harper \& Row.

Connolly, J., Sebastià, M.-T., Kirwan, L., Finn, J. A., Llurba, R., Suter, M., Lüscher, A. (2018). Weed suppression greatly increased by plant diversity in intensively managed grasslands: A continentalscale experiment. Journal of Applied Ecology, 55(2), 852-862. https://doi. org/10.1111/13652664.12991

Corbin, J. D., \& D'Antonio, C. M. (2004). Competition between native perennial and exotic annual grasses: Implications for an historical invasion. Ecology, 85(5), 1273-1283.

https://doi.org/10.1890/02-0744

Daneshgar, P., \& Jose, S. (2009). Role of species identity in plant invasions: Experimental test using Imperata cylindrica. Biological Invasions, 11(6), 1431-1440. https://doi.org/10.1007/s10530-0089351-x 
Davis, M. A., Grime, J. P., \& Thompson, K. (2000). Fluctuating resources in plant communities: A general theory of invasibility. Journal of Ecology, 88(3), 528-534. https://doi.org/10.1046/j.13652745.2000.00473.x

Dawson, W., Fischer, M., \& van Kleunen, M. (2011). The maximum relative growth rate of common UK plant species is positively associated with their global invasiveness. Global Ecology and Biogeography, 20(2), 299-306. https://doi.org/10.1111/j.1466-8238.2010.00599.x

Diamond, J. M. (1975). Assembly of species communities. In M. L. Cody \& J. M. Diamond (Eds.), Ecology and evolution of communities (pp. 342-344). Cambridge, MA: Harvard University Press.

Dickson, T. L., Hopwood, J. L., \& Wilsey, B. J. (2012). Do priority effects benefit invasive plants more than native plants? An experiment with six grassland species. Biological Invasions, 14(12), 26172624. https://doi.org/10.1007/s10530-012-0257-2

Divíšek, J., Chytrý, M., Beckage, B., Gotelli, N. J., Lososová, Z., Pyšek, P., Molofsky, J. (2018). Similarity of introduced plant species to native ones facilitates naturalization, but differences enhance invasion success. Nature Communications, 9(1), 4631. https://doi.org/10.1038/ s41467-018-06995-4

Drenovsky, R. E., \& James, J. J. (2010). Designing invasion-resistant plant communities: The role of plant functional traits. Rangelands, 32(1), 32-37. https://doi.org/10.2111/RANGELANDS-D-0900002.1

Dukes, J. S. (2002). Species composition and diversity affect grassland susceptibility and response to invasion. Ecological Applications, 12(2), 602-617. https://doi.org/10.1890/1051-

0761(2002)012[0602: SCADAG]2.0.CO;2

Emery, S. M. (2007). Limiting similarity between invaders and dominant species in herbaceous plant communities? Journal of Ecology, 95(5), 1027-1035. https://doi.org/10.1111/j.1365-

2745.2007.01274.x

Eriksson, O., Wikström, S., Eriksson, Å., \& Lindborg, R. (2006). Species-rich Scandinavian grasslands are inherently open to invasion. Biological Invasions, 8(2), 355-363.

https://doi.org/10.1007/ s10530-004-4720-6

Fargione, J., Brown, C. S., \& Tilman, D. (2003). Community assembly and invasion: An experimental test of neutral versus niche processes. Proceedings of the National Academy of Sciences of the United States of America, 100(15), 8916-8920. https://doi.org/10.1073/pnas.10331 07100

Fargione, J., \& Tilman, D. (2005). Niche differences in phenology and rooting depth promote coexistence with a dominant C4 bunchgrass. Oecologia, 143(4), 598-606.

https://doi.org/10.1007/s00442005-0010-y

Fargione, J., Tilman, D., Dybzinski, R., Lambers, J. H. R., Clark, C., Harpole, W. S., ... Loreau, M. (2007). From selection to complementarity: Shifts in the causes of biodiversity-productivity relationships in a long-term biodiversity experiment. Proceedings of the Royal Society of London B: Biological Sciences, 274(1611), 871-876. https://doi. org/10.1098/rspb.2006.0351

Fenner, M., \& Thompson, K. (2005). The ecology of seeds. Cambridge, UK: Cambridge University Press. 
Firn, J., MacDougall, A. S., Schmidt, S., \& Buckley, Y. M. (2010). Early emergence and resource availability can competitively favour natives over a functionally similar invader. Oecologia, 163(3), 775-784. https://doi.org/10.1007/s00442-010-1583-7

Freckleton, R. P., \& Watkinson, A. R. (2001). Asymmetric competition between plant species. Functional Ecology, 15(5), 615-623. https://doi. org/10.1046/j.0269-8463.2001.00558.x

Fukami, T. (2015). Historical contingency in community assembly: Integrating niches, species pools, and priority effects. Annual Review of Ecology, Evolution, and Systematics, 46, 1-23. https://doi. org/10.1146/annurev-ecolsys-110411-160340

Fukami, T., Martijn Bezemer, T., Mortimer, S. R., \& van der Putten, W.H. (2005). Species divergence and trait convergence in experimental plant community assembly. Ecology Letters, 8(12), 1283-1290. https://doi.org/10.1111/j.1461-0248.2005.00829.x

Fumanal, B., Gaudot, I., \& Bretagnolle, F. (2008). Seed-bank dynamics in the invasive plant, Ambrosia artemisiifolia L. Seed Science Research, 18(2), 101-114.

https://doi.org/10.1017/S0960258508974316

Funk, J. L., Cleland, E. E., Suding, K. N., \& Zavaleta, E. S. (2008). Restoration through reassembly: Plant traits and invasion resistance. Trends in Ecology \& Evolution, 23(12), 695-703. https://doi. org/10.1016/j.tree.2008.07.013

Funk, J. L., \& Wolf, A. A. (2016). Testing the trait-based community framework: Do functional traits predict competitive outcomes? Ecology, 97(9), 2206-2211. https://doi.org/10.1002/ecy.1484

Gause, G. F. (1934). The struggle for existence. Baltimore, MD: Williams and Wilkins.

Goldberg, D. E. (1996). Competitive ability: Definitions, contingency and correlated traits.

Philosophical Transactions of the Royal Society B, 351(1345), 1377-1385.

https://doi.org/10.1098/rstb.1996.0121

Grman, E., \& Suding, K. N. (2010). Within-year soil legacies contribute to strong priority effects of exotics on native California grassland communities. Restoration Ecology, 18(5), 664-670. https://doi. org/10.1111/j.1526-100X.2008.00497.x

Grubb, P. J. (1986). Problems posed by sparse and patchily distributed species in species-rich plant communities. In J. Diamond \& T. J. Case (Eds.), Community ecology (pp. 207-225). New York, NY: Harper \& Row.

Hallett, S. G. (2006). Dislocation from coevolved relationships: A unifying theory for plant invasion and naturalization? Weed Science, 54(2), 282-290. https://doi.org/10.1614/WS-05-100R2.1

Hamilton, M. A., Murray, B. R., Cadotte, M. W., Hose, G. C., Baker, A. C., Harris, C. J., \& Licari, D. (2005). Life-history correlates of plant invasiveness at regional and continental scales. Ecology Letters, 8(10), 1066-1074. https://doi.org/10.1111/j.1461-0248.2005.00809.x

Herben, T., \& Goldberg, D. E. (2014). Community assembly by limiting similarity vs. competitive hierarchies: Testing the consequences of dispersion of individual traits. Journal of Ecology, 102(1), 156-166. https://doi.org/10.1111/1365-2745.12181

Hess, M. C. M., Mesléard, F., \& Buisson, E. (2019). Priority effects: Emerging principles for invasive plant species management. Ecological Engineering, 127, 48-57. https://doi.org/10.1016/j.ecoleng. 2018.11.011 
Honig, M. A., Cowling, R. M., \& Richardson, D. M. (1992). The invasive potential of Australian banksias in South African fynbos: A comparison of the reproductive potential of Banksia ericifolia and Leucadendron laureolum. Australian Journal of Ecology, 17(3), 305-314. https://doi. org/10.1111/j.1442-9993.1992.tb00812.x

Hooper, D. U., \& Dukes, J. S. (2010). Functional composition controls invasion success in a California serpentine grassland. Journal of Ecology, 98(4), 764-777. https://doi.org/10.1111/j.1365-

2745.2010.01673.x

Hubbell, S. P. (2005). Neutral theory in community ecology and the hypothesis of functional equivalence. Functional Ecology, 19(1), 166- 172. https://doi.org/10.1111/j.0269-8463.2005.00965.x

Hutchinson, G. E. (1957). Concluding remarks. Cold Spring Harbor Symposia on Quantitative Biology, 22, 415-427. https://doi.org/10.1101/ SQB.1957.022.01.039

Hutchinson, G. E. (1959). Homage to Santa Rosalia; or, why are there so many kinds of animals. The American Naturalist, 93, 145-159. https:// doi.org/10.1086/282070

Johansson, M. E., \& Keddy, P. A. (1991). Intensity and asymmetry of competition between plant pairs of different degrees of similarity: An experimental study on two guilds of wetland plants. Oikos, 60(1), 27-34. https://doi.org/10.2307/3544988

Keddy, P. A., \& Shipley, B. (1989). Competitive hierarchies in herbaceous plant communities. Oikos, 54(2), 234-241. https://doi. org/10.2307/3565272

Kuebbing, S. E., Nuñez, M. A., \& Simberloff, D. (2013). Current mismatch between research and conservation efforts: The need to study co-occurring invasive plant species. Biological Conservation, 160, 121-129. https://doi.org/10.1016/j.biocon.2013.01.009

Kunstler, G., Lavergne, S., Courbaud, B., Thuiller, W., Vieilledent,G., Zimmermann, N. E., ... Coomes, D. A. (2012). Competitive interactions between forest trees are driven by species' trait hierarchy, not phylogenetic or functional similarity: Implications for forest community assembly. Ecology Letters, 15(8), 831-840. https://doi. org/10.1111/j.1461-0248.2012.01803.x

Larson, D. L., Bright, J. B., Drobney, P., Larson, J. L., Palaia, N., Rabie, P. A., ... Wells, D. (2013). Using prairie restoration to curtail invasion of Canada thistle: The importance of limiting similarity and seed mix richness. Biological Invasions, 15(9), 2049-2063. https://doi. org/10.1007/s10530-013-0432-0

Lavorel, S., \& Garnier, É. (2002). Predicting changes in community composition and ecosystem functioning from plant traits: Revisiting the Holy Grail. Functional Ecology, 16(5), 545-556. https://doi. org/10.1046/j.1365-2435.2002.00664.x

Lavorel, S., Prieur-Richard, A. H., \& Grigulis, K. (1999). Invasibility and diversity of plant communities: From patterns to processes. Diversity and Distributions, 5(1-2), 41-49. https://doi. org/10.1046/j.1472-4642.1999.00034.x

Longo, G., Seidler, T. G., Garibaldi, L. A., Tognetti, P. M., \& Chaneton, E.J. (2013). Functional group dominance and identity effects influence the magnitude of grassland invasion. Journal of Ecology, 101(5), 1114-1124. https://doi.org/10.1111/1365-2745.12128

MacArthur, R., \& Levins, R. (1964). Competition, habitat selection, and character displacement in a patchy environment. Proceedings of the National Academy of Sciences, 51(6), 1207-1210. https://doi. org/10.1073/pnas.51.6.1207 
MacArthur, R., \& Levins, R. (1967). The limiting similarity, convergence, and divergence of coexisting species. The American Naturalist, 101(921), 377-385. https://doi.org/10.1086/282505

Mahdi, A., Law, R., \& Willis, A. J. (1989). Large niche overlaps among coexisting plant species in a limestone grassland community. The Journal of Ecology, 77(2), 386-400. https://doi.org/10.2307/ 2260757

Martin, L. M., \& Wilsey, B. J. (2012). Assembly history alters alpha and beta diversity, exotic-native proportions and functioning of restored prairie plant communities. Journal of Applied Ecology, 49(6), 1436- 1445. https://doi.org/10.1111/j.1365-2664.2012.02202.x

Marushia, R. G., Cadotte, M. W., \& Holt, J. S. (2010). Phenology as a basis for management of exotic annual plants in desert invasions. Journal of Applied Ecology, 47(6), 1290-1299. https://doi. org/10.1111/j.1365-2664.2010.01881.x

Mason, N. W., \& Wilson, J. B. (2006). Mechanisms of species coexistence in a lawn community: Mutual corroboration between two independent assembly rules. Community Ecology, 7(1), 109-116. https://doi. org/10.1556/ComEc.7.2006.1.11

McGeoch, M. A., Butchart, S. H. M., Spear, D., Marais, E., Kleynhans,

E. J., Symes, A., ... Hoffmann, M. (2010). Global indicators of biological invasion: Species numbers, biodiversity impact and policy responses. Diversity and Distributions, 16(1), 95-108. https://doi. org/10.1111/j.1472-4642.2009.00633.x

McGill, B. J., Enquist, B. J., Weiher, E., \& Westoby, M. (2006). Rebuilding community ecology from functional traits. Trends in Ecology \& Evolution, 21(4), 178-185.

https://doi.org/10.1016/j.tree. 2006.02.002

Mesléard, F., Ham, L. T., Boy, V., van Wijck, C., \& Grillas, P. (1993). Competition between an introduced and an indigenous species: The case of Paspalum paspalodes (Michx) Schribner and Aeluropus littoralis (Gouan) in the Camargue (southern France). Oecologia, 94(2), 204- 209. https://doi.org/10.1007/BF00341318

Naeem, S., Knops, J. M., Tilman, D., Howe, K. M., Kennedy, T., \& Gale, S. (2000). Plant diversity increases resistance to invasion in the absence of covarying extrinsic factors. Oikos, 91(1), 97-108. https://doi. org/10.1034/j.1600-0706.2000.910108.x

Öster, M., \& Eriksson, O. (2012). Recruitment in species-rich grasslands: The effects of functional traits and propagule pressure. Plant Ecology, 5(3), 260-269. https://doi.org/10.1093/jpe/rtr027

Passarge, J., Hol, S., Escher, M., \& Huisman, J. (2006). Competition for nutrients and light: Stable coexistence, alternative stable states, or competitive exclusion? Ecological Monographs, 76(1), 57-72. https://doi.org/10.1890/04-1824

Price, J. N., \& Pärtel, M. (2013). Can limiting similarity increase invasion resistance? A meta-analysis of experimental studies. Oikos, 122(5), 649-656. https://doi.org/10.1111/j.1600-0706.2012.00121.x

Prieur-Richard, A. H., Lavorel, S., Grigulis, K., \& Dos Santos, A. (2000). Plant community diversity and invasibility by exotics: Invasion of Mediterranean old fields by Conyza bonariensis and Conyza canadensis. Ecology Letters, 3(5), 412-422. https://doi. org/10.1046/j.1461-

0248.2000.00157.x 
Pyke, D. A. (1990). Comparative demography of co-occurring introduced and native tussock grasses: Persistence and potential expansion. Oecologia, 82(4), 537-543.https://doi.org/10.1007/BF00319798

Rejmánek, M., \& Richardson, D. M. (1996). What attributes make some plant species more invasive? Ecology, 77(6), 1655-1661. https://doi. org/10.2307/2265768

Renne, I. J., Barrow, W. C. Jr, Johnson Randall, L. A., \& Bridges, W.C. Jr (2002). Generalized avian dispersal syndrome contributes to Chinese tallow tree (Sapium sebiferum, Euphorbiaceae) invasiveness. Diversity and Distributions, 8(5), 285-295. https://doi. org/10.1046/j.14724642.2002.00150.x

Schnitzer, S. A., Kuzee, M. E., \& Bongers, F. (2005). Disentangling above-and below-ground competition between lianas and trees in a tropical forest. Journal of Ecology, 93(6), 1115-1125. https://doi. org/10.1111/j.1365-2745.2005.01056.x

Shea, K., \& Chesson, P. (2002). Community ecology theory as a framework for biological invasions. Trends in Ecology \& Evolution, 17(4), 170-176. https://doi.org/10.1016/S0169-5347(02)02495-3

Sheley, R. L., \& James, J. (2010). Resistance of native plant functional groups to invasion by medusahead (Taeniatherum caput-medusae). Invasive Plant Science and Management, 3(3), 294300. https://doi. org/10.1614/IPSM-D-09-00056.1

Sheley, R. L., Svejcar, T. J., \& Maxwell, B. D. (1996). A theoretical framework for developing successional weed management strategies on rangeland. Weed Technology, 10(4), 766-773. https://doi. org/10.1017/S0890037X00040793

Shen, Y., Liu, W., Baskin, J. M., Baskin, C. C., \& Cao, M. (2006). Persistent soil seed banks of the globally significant invasive species, Eupatorium adenophorum, in Yunnan Province, south-western China. Seed Science Research, 16(2), 157-162. https://doi.org/10.1079/SSR2006240

Silvertown, J. (2004). Plant coexistence and the niche. Trends in Ecology \& Evolution, 19(11), 605-611. https://doi.org/10.1016/j. tree.2004.09.003

Simberloff, D., Martin, J.-L., Genovesi, P., Maris, V., Wardle, D. A., Aronson, J., ... Vilà, M. (2013). Impacts of biological invasions: What's what and the way forward. Trends in Ecology \& Evolution, 28(1), 58-66. https://doi.org/10.1016/j.tree.2012.07.013

Stansbury, C. D. (2001). Dispersal of the environmental weed Bridal Creeper, Asparagus asparagoides, by Silvereyes, Zosterops lateralis, in south-western Australia. Emu, 101(1), 39-45. https://doi. org/10.1071/MU00069

Stohlgren, T. J., Barnett, D. T., Jarnevich, C. S., Flather, C., \& Kartesz, J. (2008). The myth of plant species saturation. Ecology Letters, 11(4), 313-322. https://doi.org/10.1111/j.14610248.2008.01153.x

Stubbs, W. J., \& Wilson, J. B. (2004). Evidence for limiting similarity in a sand dune community. Journal of Ecology, 92(4), 557-567. https://doi. org/10.1111/j.0022-0477.2004.00898.x

Stuble, K. L., \& Souza, L. (2016). Priority effects: Natives, but not exotics, pay to arrive late. Journal of Ecology, 104(4), 987-993. https://doi. org/10.1111/1365-2745.12583

Symstad, A. J. (2000). A test of the effects of functional group richness and composition on grassland invasibility. Ecology, 81(1), 99-109. https://doi.org/10.1890/0012-9658(2000)081[0099:ATOTEO] 2.0.CO;2 
Tilman, D. (1982). Resource competition and community structure.Princeton, NJ: Princeton University Press.

Tilman, D. (2004). Niche tradeoffs, neutrality, and community structure: A stochastic theory of resource competition, invasion, and community assembly. Proceedings of the National Academy of Sciences of the United States of America, 101(30), 10854-10861. https://doi.

org/10.1073/pnas.0403458101

Turnbull, L. A., Coomes, D., Hector, A., \& Rees, M. (2004). Seed mass and the competition/colonization trade-off: Competitive interactions and spatial patterns in a guild of annual plants. Journal of Ecology, 92(1), 97-109. https://doi.org/10.1111/j.1365-2745.2004. 00856.x

Turnbull, L. A., Rahm, S., Baudois, O., Eichenberger-Glinz, S., Wacker, L., \&Schmid, B. (2005). Experimental invasion by legumes reveals non-random assembly rules in grassland communities. Journal of Ecology, 93(6), 1062-1070. https://doi.org/10.1111/j.1365-2745.2005.01051.x

Vance, R. R. (1984). Interference competition and the coexistence of two competitors on a single limiting resource. Ecology, 65(5), 1349-1357. https://doi.org/10.2307/1939115

Vaughn, K. J., \& Young, T. P. (2015). Short-term priority over exotic annuals increases the initial density and longer-term cover of native perennial grasses. Ecological Applications, 25(3), 791-799. https://doi. org/10.1890/14-0922.1

von Holle, B. (2005). Biotic resistance to invader establishment of a southern Appalachian plant community is determined by environmental conditions. Journal of Ecology, 93(1), 16-26. https://doi. org/10.1111/j.0022-0477.2004.00946.x

Walder, M., Armstrong, J. E., \& Borowicz, V. A. (2018). Limiting similarity, biotic resistance, nutrient supply, or enemies? What accounts for the invasion success of an exotic legume? Biological Invasions, 21(2), 435-449. https://doi.org/10.1007/s10530-018-1835-8

Wang, J., Ge, Y., Zhang, C. B., Bai, Y., \& Du, Z. K. (2013). Dominant functional group effects on the invasion resistance at different resource levels. PLoS ONE, 8(10), e77220.

https://doi.org/10.1371/journ al.pone.0077220

Wedin, D., \& Tilman, D. (1993). Competition among grasses along a nitrogen gradient: Initial conditions and mechanisms of competition. Ecological Monographs, 63(2), 199-229. https://doi.org/10.2307/2937180

Wilsey, B. J., Barber, K., \& Martin, L. M. (2015). Exotic grassland species have stronger priority effects than natives regardless of whether they are cultivated or wild genotypes. New Phytologist, 205(2), 928-937. https://doi.org/10.1111/nph.13028

Wilson, J. B. (2007). Trait-divergence assembly rules have been demonstrated: Limiting similarity lives! A reply to Grime. Journal of Vegetation Science, 18(3), 451-452.

https://doi.org/10.1111/j.1654-1103.2007. tb02557.x

Wilson, J. B., \& Whittaker, R. J. (1995). Assembly rules demonstrated in a saltmarsh community. The Journal of Ecology, 83(5), 801-807. https://doi.org/10.2307/2261417

Yannelli, F. A., Hughes, P., \& Kollmann, J. (2017). Preventing plant invasions at early stages of revegetation: The role of limiting similarity in seed size and seed density. Ecological Engineering, 100, 286-290. https://doi.org/10.1016/j.ecoleng.2016.12.001 
Yannelli, F. A., Karrer, G., Hall, R., Kollmann, J., \& Heger, T. (2018). Seed density is more effective than multi-trait limiting similarity in controlling grassland resistance against plant invasions in mesocosms. Applied Vegetation Science, 21(3), 411-418. https://doi.org/10.1111/ avsc.12373

Young, T. P., Stuble, K. L., Balachowski, J. A., \& Werner, C. M. (2016). Using priority effects to manipulate competitive relationships in restoration. Restoration Ecology, 25, 114-123.

https://doi.org/10.1111/ rec.12384 